\title{
Microhardness of glass ionomer cements indicated for the ART technique according to surface protection treatment and storage time
}

\begin{abstract}
Luciana Keiko Shintome ${ }^{(a)}$ Marcos Paulo Nagayassu(a) Rebeca Di Nicoló(b) Silvio Issáo Myaki ${ }^{(b)}$
\end{abstract}

(a) $\mathrm{PhD}$, Department of Restorative Dentistry, School of Dentistry of São José dos Campos, São Paulo State University (UNESP), São José dos Campos, SP, Brazil.

(b) Associate Professor, Department of Pediatric Dentistry, School of Dentistry of São José dos Campos, São Paulo State University (UNESP), São José dos Campos, SP, Brazil.

\begin{abstract}
The aim of this study was to assess the microhardness of 5 glass ionomer cements (GIC) - Vidrion R (V, SS White), Fuji IX (F, GC Corp.), Magic Glass ART (MG, Vigodent), Maxxion R (MR, FGM) and ChemFlex (CF, Dentsply) - in the presence or absence of a surface protection treatment, and after different storage periods. For each GIC, 36 test specimens were made, divided into 3 groups according to the surface protection treatment applied - no protection, varnish or nail varnish. The specimens were stored in distilled water for $24 \mathrm{~h}, 7$ and 30 days and the microhardness tests were performed at these times. The data obtained were submitted to the ANOVA for repeated measures and Tukey tests ( $\alpha=5 \%$ ). The results revealed that the mean microhardness values of the GICs were, in decreasing order, as follows: $\mathrm{F}>\mathrm{CF}=\mathrm{MR}>\mathrm{MG}>\mathrm{V}$; that surface protection was significant for $\mathrm{MR}$, at $24 \mathrm{~h}$, without protection $(64.2 \pm 3.6 \mathrm{a})$, protected with GIC varnish $(59.6 \pm 3.4 \mathrm{~b})$ and protected with nail varnish $(62.7 \pm 2.8 \mathrm{ab})$; for $\mathrm{F}$, at 7 days, without protection $(97.8 \pm 3.7 \mathrm{ab})$, protected with varnish $(95.9 \pm 3.2 \mathrm{~b})$ and protected with nail varnish $(100.8 \pm 3.4 \mathrm{a})$; and at 30 days, for $\mathrm{F}$, without protection $(98.8 \pm 2.6 \mathrm{~b})$, protected with varnish $(103.3 \pm 4.4 \mathrm{a})$ and protected with nail varnish $(101 \pm 4.1 \mathrm{ab})$ and, for $\mathrm{V}$, without protection $(46 \pm 1.3 \mathrm{~b})$, protected with varnish $(49.6 \pm 1.7 \mathrm{ab})$ and protected with nail varnish $(51.1 \pm 2.6 \mathrm{a})$. The increase in storage time produced an increase in microhardness. It was concluded that the different GICs, surface protection treatments and storage times could alter the microhardness values.
\end{abstract}

Descriptors: Glass ionomer cements; Hardness tests; Varnish, cavity.
Corresponding author: Luciana Keiko Shintome

R. Alexandre de Melo e Faro, 45,

Vila Aparecida

Ribeirão Pires - SP - Brazil

CEP: 09406-160

E-mail: lushintome@ig.com.br
Received for publication on May 12, 2008

Accepted for publication on Feb 08, 2009 


\section{Introduction}

Dental caries and its effects remain a serious public health problem, presenting a high incidence in the needier population that does not have access to curative or preventive treatments. ${ }^{1}$ In Brazil, it is responsible for the loss of teeth in the entire population, irrespective of age, with a greater tendency in the low income population. ${ }^{2}$

With the objective of bringing dental treatment to this portion of the population that has no access to conventional treatment, a new treatment modality was developed for caries disease: the Atraumatic Restorative Treatment (ART). This technique is based on the partial removal of carious tissue, using only manual cutting instruments, filling the dental cavity and sealing the adjacent pits and fissures with a material that has adhesive characteristics, such as Glass Ionomer Cement (GIC), without requiring electrical power. ${ }^{1}$

The high-viscosity GICs were developed specifically for this technique. They have higher mean compression strength, mean wear resistance and material surface hardness values ${ }^{3}$ when compared with the conventional GICs and some of the resinmodified GICs. ${ }^{3,4,5}$

In spite of the improvement in the mechanical properties and manipulation characteristics of the GICs indicated for the ART technique, the setting reaction of this material continues to be prolonged, and premature exposure to humidity or excessive drying could cause deleterious effects on the material, since water is essential for the formation of the cement matrix, and it is very important to maintain a hydric balance in the material. ${ }^{6}$

According to Ellakuria et al. ${ }^{7}$ (2003), there are changes in the mechanical properties of GICs over the course of time. This phenomenon could be related to the acid-base reaction that occurs slowly, indicating that the initial properties of the material may not be the same after a period of time.

Aiming at obtaining the maximum benefit from the mechanical properties of this material, various authors have recommended the use of surface protection agents, particularly in the initial stage of jellification. Among these agents are cavity varnishes, agents supplied by the material manufacturer itself, light activated adhesive systems, cocoa butter, Vaseline and nail varnish. , $^{8,9,10,11}$

Research has shown that the ART technique could contribute to improve the oral health of the population as a whole, and it is a low cost technique because it does not require the installation of costly equipment for dental treatment. Nevertheless, in Brazil the high cost of the GIC recommended for this technique ends up limiting its application. Over the last few years, some Brazilian GICs have been produced to address that impediment but few studies have evaluated their physical properties. ${ }^{12}$

In view of the above, a justification was found for developing a comparative study with regard to the microhardness of different glass ionomer cements indicated for the ART technique, according to different surface protection treatments and storage times.

\section{Materials and Methods}

The glass ionomer cements (GICs) evaluated in this study were as follows: Fuji IX (F) - GC Corp. (Itabashi-ku, Tokyo, Japan), Magic Glass ART (MG) - Vigodent (Rio de Janeiro, RJ, Brazil), Maxxion R (MR) - FGM (Joinville, SC, Brazil), and ChemFlex (CF) - Dentsply (Petrópolis, RJ, Brazil). These GICs are indicated for the ART technique. The conventional GIC Vidrion R (V) - SS White (Rio de Janeiro, RJ, Brazil) was used as a control. All the materials used were proportioned and manipulated according to the instructions of their respective manufacturers (Table 1).

For each type of GIC, 36 test specimens were made with the aid of a two-piece Teflon matrix, with four cylindrical cavities ( $3 \mathrm{~mm} \times 3 \mathrm{~mm}$ ). The matrix was filled with GIC, covered with a matrix polyester strip $(3 \mathrm{M})$, followed by a glass slide. To press this set against the top portion of the matrix and keep it in position for $7 \mathrm{~min},{ }^{13}$ a $200 \mathrm{~g}$ weight was placed on top of the set, thus standardizing the pressure exerted during the initial setting of the material. The test specimens of each material were subdivided into 3 groups, according to the surface protection treatment performed.

For Fuji IX GP (F), the specimens were randomly subdivided into 3 groups. In Group F1 $(\mathrm{n}=12)$ the 
Table 1 - Glass ionomer formulations used in the study.

\begin{tabular}{l|l|l|c}
\hline \multicolumn{1}{c|}{ Product } & \multicolumn{1}{c|}{ Powder } & \multicolumn{1}{c}{ Liquid } & Powder/Liquid \\
\hline $\begin{array}{l}\text { Vidrion R } \\
\text { (SS White) }\end{array}$ & $\begin{array}{l}\text { Sodium fluorosilicate calcium and aluminium; } \\
\text { barium sulfate; polyacrylic acid and pigments }\end{array}$ & Tartaric acid and distilled water & $\begin{array}{c}1 \mathrm{scoop} / 1 \mathrm{drop} \\
(2.6 \mathrm{~g} / 1.0 \mathrm{~g})\end{array}$ \\
\hline $\begin{array}{l}\text { Fuji IX } \\
\text { (GC) }\end{array}$ & Alumino fluoro silicate glass; polyacrylic acid & $\begin{array}{l}\text { Distilled water; polyacrylic acid; } \\
\text { polybasic carboxylic acid }\end{array}$ & $\begin{array}{c}1 \mathrm{scoop} / 1 \mathrm{drop} \\
(3.6 \mathrm{~g} / 1.0 \mathrm{~g})\end{array}$ \\
\hline $\begin{array}{l}\text { Magic Glass ART } \\
\text { (Vigodent) }\end{array}$ & $\begin{array}{l}\text { Radiopaque fluoraluminium silicate crystals; } \\
\text { polycarboxilic acid and pigments }\end{array}$ & $\begin{array}{l}\text { Polycarboxilic acid; maleic acid; } \\
\text { itaconic acid and purified water }\end{array}$ & $\begin{array}{c}1 \mathrm{scoop} / 1 \mathrm{drop} \\
(2.7 \mathrm{~g} / 1.0 \mathrm{~g})\end{array}$ \\
\hline $\begin{array}{l}\text { Maxxion R } \\
\text { (FGM) }\end{array}$ & $\begin{array}{l}\text { Glass of fluoro aluminium silicate, calcium fluoride } \\
\text { and pigments }\end{array}$ & Polyacrylic acid and water & $1 \mathrm{scoop} / 1 \mathrm{drop}$ \\
$(2.5 \mathrm{~g} / 1.0 \mathrm{~g})$
\end{tabular}

Table 2 - RM ANOVA of the data.

\begin{tabular}{l|r|r|r|r|l}
\hline \multicolumn{1}{c|}{ Effects } & \multicolumn{1}{c|}{ df } & \multicolumn{1}{c|}{ SS } & \multicolumn{1}{c|}{ MS } & \multicolumn{1}{c|}{ F } & p-value \\
\hline GIC & 4 & 171,439 & $42,859.8$ & $3,950.89$ & $0.0001^{*}$ \\
\hline Surface protection (SP) & 2 & 169 & 84.5 & 7.79 & $0.0006^{*}$ \\
\hline GIC X SP & 8 & 566 & 70.8 & 6.52 & $0.0001^{*}$ \\
\hline Residue I & 165 & 1,790 & 10.8 & & \\
\hline Time (T) & 2 & 10,322 & $5,161.2$ & 554.00 & $0.0001^{*}$ \\
\hline GIC X T & 8 & 2,298 & 287.3 & 30.83 & $0.0001^{*}$ \\
\hline SPXT & 4 & 281 & 70.3 & 7.55 & $0.0001^{*}$ \\
\hline GICXSPXT & 16 & 523 & 32.7 & 3.51 & $0.0001^{*}$ \\
\hline Residue II & 330 & 3,074 & 9.3 & & \\
\hline Total & 539 & 190,463 & & & \\
\hline${ }^{*} \mathrm{p}<0.05$. & & & &
\end{tabular}

specimens received no surface protection whatsoever; in Group F2 $(n=12)$ the specimens were protected with a coat of nail varnish. In Group F3 ( $n=12)$ the samples received the application of a coat of varnish recommended by the manufacturer, with a disposable brush, on the entire exposed surface of the cement, followed by a brief air stream, and light activation for $10 \mathrm{~s}$.

The same procedure was repeated for the other materials evaluated.

Next, all the specimens were immersed in distilled water and stored at $37^{\circ} \mathrm{C}$ for $24 \mathrm{~h}, 7$ and 30 days before performing the microhardness tests.

To evaluate microhardness, two diagonal marks were made on each test specimen with the aid of a \#11 scalpel blade, dividing the surface into four quadrants. After this, the test specimens were taken to the microhardness tester FM-700 (Future-Tech
Corp. Tokyo, Japan), equipped with a Vickers diamond that was applied on each quadrant with a load of $50 \mathrm{~g} / 30 \mathrm{~s}$. The test was repeated at the times of 24 h, 7 and 30 days.

With the aim of analyzing the influence of GIC, surface protection treatment and storage time on surface microhardness, an experiment that follows a factorial scheme $(5 \times 3 \times 3)$ was designed, totaling 45 experimental conditions with 12 repetitions, in which the factor time is the repeated measure.

The data obtained were submitted to the ANOVA for repeated measures and the Tukey tests at a $5 \%$ level of significance.

\section{Results}

The data obtained were submitted to the ANOVA test for repeated measures to enable us to study the influence of the different variables (GIC, surface 
Table 3 - Means ( \pm standard deviation) (Vickers) of the microhardness values obtained at $24 \mathrm{~h}$.

\begin{tabular}{c|c|c|c}
\hline \multirow{2}{*}{ GIC } & \multicolumn{3}{|c}{ Surface protection } \\
\cline { 2 - 4 } & Without protection & Nail varnish & Varnish \\
\hline$F$ & $89.85 \pm 3.17^{\mathrm{A}}$ & $86.89 \pm 3.44^{\mathrm{A}}$ & $90.42 \pm 2.63^{\mathrm{A}}$ \\
\hline MR & $64.15 \pm 3.62^{\mathrm{B}}$ & $62.74 \pm 2.82^{\mathrm{BC}}$ & $59.64 \pm 3.44^{\mathrm{C}}$ \\
\hline CF & $52.52 \pm 3.57^{\mathrm{D}}$ & $51.76 \pm 3.03^{\mathrm{D}}$ & $53.66 \pm 5.38^{\mathrm{D}}$ \\
\hline MG & $49.18 \pm 2.88^{\mathrm{DE}}$ & $46.84 \pm 3.89^{\mathrm{E}}$ & $45.21 \pm 1.89^{\mathrm{E}}$ \\
\hline$V$ & $35.08 \pm 1.65^{\mathrm{F}}$ & $37.49 \pm 2.94^{\mathrm{F}}$ & $38.19 \pm 2.75^{\mathrm{F}}$ \\
\hline
\end{tabular}

Different letters indicate statistically significant difference.

Table 5 - Means ( \pm standard deviation) (Vickers) of the microhardness values obtained at 30 days.

\begin{tabular}{c|c|c|c}
\hline \multirow{2}{*}{ GIC } & \multicolumn{3}{|c}{ Surface protection } \\
\cline { 2 - 4 } & Without protection & Nail varnish & Varnish \\
\hline$F$ & $98.77 \pm 2.64^{\mathrm{B}}$ & $100.99 \pm 4.10^{\mathrm{AB}}$ & $103.27 \pm 4.39^{\mathrm{A}}$ \\
\hline MR & $68.88 \pm 3.91^{\mathrm{C}}$ & $68.68 \pm 3.05^{\mathrm{C}}$ & $68.92 \pm 4.19^{\mathrm{C}}$ \\
\hline CF & $69.13 \pm 3.58^{\mathrm{C}}$ & $68.29 \pm 2.81^{\mathrm{C}}$ & $67.46 \pm 3.63^{\mathrm{C}}$ \\
\hline$M G$ & $50.87 \pm 2.02^{\mathrm{DE}}$ & $53.89 \pm 1.52^{\mathrm{E}}$ & $52.47 \pm 1.83^{\mathrm{DE}}$ \\
\hline$V$ & $45.95 \pm 1.34^{\mathrm{F}}$ & $51.10 \pm 2.62^{\mathrm{DE}}$ & $49.59 \pm 1.72^{\mathrm{EF}}$ \\
\hline
\end{tabular}

Different letters indicate statistically significant difference.

protection treatment and storage time) on the microhardness values obtained. It was observed that the effect of the interaction among the three studied variables was statistically significant (Table 2). This effect can be observed in Graph 1, which indicates that the relationship GIC X storage time, without surface protection, is not the same as the relationship with surface protection with nail varnish and with varnish.

After this, we studied the relationship between GIC and surface protection separately, for the times of 24 h, 7 and 30 days (Tables 3, 4 and 5).

The highest mean microhardness values were obtained for Fuji IX, without presenting significant difference among the types of protection used. The GIC that presented the lowest mean microhardness values after $24 \mathrm{~h}$ of storage was Vidrion $\mathrm{R}$, and there was no difference between the different types of protection used (Table 3).

Maxxion $\mathrm{R}$ was the only material that presented mean microhardness values that showed statistically
Table 4 - Means ( \pm standard deviation) (Vickers) of the microhardness values obtained at 7 days.

\begin{tabular}{c|c|c|c}
\hline \multirow{2}{*}{ GIC } & \multicolumn{3}{|c}{ Surface protection } \\
\cline { 2 - 4 } & Without protection & Nail varnish & Varnish \\
\hline$F$ & $97.79 \pm 3.71^{\mathrm{AB}}$ & $100.80 \pm 3.39^{\mathrm{A}}$ & $95.87 \pm 3.23^{\mathrm{B}}$ \\
\hline MR & $61.56 \pm 4.10^{\mathrm{C}}$ & $63.15 \pm 2.74^{\mathrm{CD}}$ & $62.64 \pm 3.25^{\mathrm{CD}}$ \\
\hline$C F$ & $64.68 \pm 1.70^{\mathrm{CD}}$ & $63.91 \pm 4.54^{\mathrm{CD}}$ & $66.89 \pm 3.22^{\mathrm{D}}$ \\
\hline$M G$ & $50.90 \pm 1.96^{\mathrm{E}}$ & $54.37 \pm 2.42^{\mathrm{E}}$ & $52.83 \pm 2.32^{\mathrm{E}}$ \\
\hline$V$ & $42.55 \pm 1.76^{\mathrm{F}}$ & $50.33 \pm 3.47^{\mathrm{F}}$ & $50.40 \pm 2.98^{\mathrm{F}}$ \\
\hline
\end{tabular}

Different letters indicate statistically significant difference.

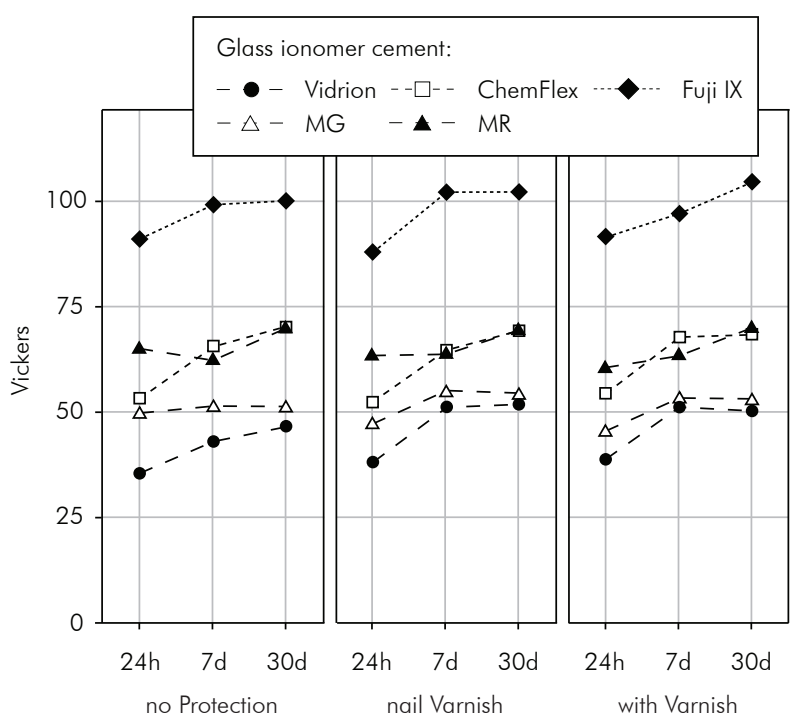

Graph 1 - Microhardness mean values (Vickers) according to the different experimental conditions.

significant differences among the different types of protection used.

For the time of 7 days of storage, the GIC that presented the best microhardness means was Fuji IX. Protection with nail varnish presented significantly higher means than those obtained with protection with varnish (Table 4).

Magic Glass ART and Vidrion R were the materials that presented the lowest mean microhardness values, and the surface protection of the specimens did not produce any alteration in the mean microhardness values observed.

For the period of 30 days, Fuji IX presented the highest mean microhardness values, the highest values corresponding to the samples that received pro- 
tection with varnish, and there was a statistically significant difference when compared with the mean values of the samples that did not receive any surface protection treatment (Table 5).

For Vidrion $\mathrm{R}$, the condition without protection presented the lowest mean microhardness values, differing statistically from the condition that received protection with nail varnish.

\section{Discussion}

GIC has been the material of choice for use with the ART technique, mainly due to its adhesive characteristics and fluoride release, ${ }^{1}$ and high-viscosity GICs are still being indicated. These have the highest powder-liquid ratio, resulting in a material that presents the least surface wear and setting time when compared with conventional GICs, ${ }^{4}$ which makes it easy to use in areas that do not have electrical power to enable the use of saliva suction devices.

However, the cost of these materials for application in public health in Brazil is very high, which has prompted the introduction of less-expensive Brazilian materials indicated for this purpose. In the present study, the microhardness of different Brazilian and imported materials indicated for the ART technique were evaluated, and the influence of surface protection and storage time - which are factors related to the longevity of the material - was also assessed.

According to Anusavice ${ }^{14}$ (2005), the term hardness is related to the resistance a material presents to indentation. Surface hardness tests appear to be appropriate for evaluating the degradation and durability of dental materials, to observe the effect of storage mediums on the surface, as indicative of resistance to wear and durability, and also to monitor the hardening process of cements. ${ }^{7,15,16,17}$

In studies conducted by Ellakuria et al. ${ }^{7}$ (2003), Peutzfeldt et al. ${ }^{5}$ (1997), Wang et al..$^{18}$ (2007), Xie et $a .^{19}$ (2000) and Yap et al. ${ }^{20}$ (2004), the GICs indicated for the ART technique presented higher microhardness values when compared with the conventional GICs, with RM-GIC and cermets. These studies are in agreement with the findings of the present research, since the GICs indicated for the ART technique used demonstrated significantly higher mean microhardness values when compared with those of the control group $(\mathrm{V})$, with the exception of the Magic Glass ART, at the time of 30 days. Nevertheless, this difference was not significant when compared with the control group values.

It was also observed that Fuji IX, under all the experimental conditions studied, presented significantly higher mean microhardness values when compared with those of the other GICs, probably due to the increase in the powder-liquid ratio, in agreement with the findings of Guggenberger et al. ${ }^{4}$ (1998), Peutzfeldt et al. ${ }^{5}$ (1997), Raggio ${ }^{12}$ (2004), Xie et al. ${ }^{19}$ (2000) and Yap et al. ${ }^{3}$ (2002).

With regard to storage time, one can observe that, with the exception of Maxxion $\mathrm{R}$, there was an increase in the microhardness values with the increase in storage time (Graph 1), in agreement with the findings of Aliping-McKenzie et al. ${ }^{15}$ (2003), Okada et al..$^{17}$ (2001), Raggio' ${ }^{12}$ (2004), Xie et al. ${ }^{19}$ (2000), Yao et al. ${ }^{21}$ (1990) and Yap et al. ${ }^{3}$ (2002). This observation leads us to reject the null hypothesis, since the storage time influenced the mean microhardness values of the GICs tested.

It could be observed that the increase in the microhardness values was more accentuated in the interval between $24 \mathrm{~h}$ and 7 days and more uniform in the interval between 7 and 30 days (Graph 1), which characterizes the setting reaction of the material. This increase in microhardness of the studied materials is probably related to the acid-base reaction that occurs in a slow and continuous manner. This reaction, which forms the cross-link of polycarboxylate chains, is a continuous process and lasts for a long period. ${ }^{6}$

In view of the results obtained, one could observe that with regard to surface protection the mean microhardness values of the studied GICs did not present the same behavior irrespective of the times tested (Table 2).

At the time of $24 \mathrm{~h}$ (Table 3), in the present study, it was observed that only Maxxion R (MR) presented mean microhardness values that differed statistically in relation to the surface protection used. The samples that did not receive any surface protection presented better microhardness means when compared with the samples that received protection with 
varnish, in agreement with the findings of Serra et al. ${ }^{9}$ (1994), in which light-activated or chemicallycured adhesive systems did not produce satisfactory surface protection, probably due to the high angle of contact formed between the adhesive and the cement, which could have harmed the bond of these two materials. According to Earl et al. ${ }^{22}$ (1989) and Watson, Banerjee ${ }^{11}$ (1993), the use of varnishes for surface protection, whether specific or not, did not prevent the movement of water from the GIC to the external environment, probably due to evaporation of the solvent that is present in its composition, which makes the varnish porous, thus allowing the movement of water into the material.

With regard to the time of 7 days (Table 4), the results revealed that only Fuji IX presented statistically significant difference in relation to the type of surface protection used. The samples that received surface protection with nail varnish presented significantly higher mean microhardness values when compared with the samples protected with varnish, in agreement with the findings of Valera et al. ${ }^{10}$ (1997) and Serra et al. ${ }^{9}$ (1994), who believe that the effectiveness of nail varnish is related to its resistance to disintegration, low permeability and hydrophobic nature, in addition to its low viscosity. According to Mount ${ }^{6}$ (1996), this low viscosity of nail varnish favors the formation of an angle of contact that allows better adaptation of the nail varnish to the ionomeric cement, thus providing better sealing.

For the time of 30 days (Table 5), the Fuji IX samples protected with varnish presented significantly higher mean microhardness values when compared with the samples that received no type of protection whatsoever, in agreement with the findings of Yao et al. ${ }^{21}$ (1990), who revealed that the use of surface protection with light-activated unfilled varnishes based on Bis-GMA (A-diglycidyl ether bisphenol dimethacrylate) were shown to be a satisfactory protection for GICs.

Furthermore, with regard to the time of 30 days, one could observe that the samples of Vidrion $\mathrm{R}$ presented higher mean microhardness values when they were protected with nail varnish in compari- son with those that received no protection, in agreement with the findings of Serra et al. ${ }^{9}$ (1994) and Cerqueira-Leite et al. ${ }^{13}$ (1999), evidencing that the surface protection against humidity was fundamental for maintaining the hardening process of the material.

A great advantage of using nail varnish for the surface protection of GICs, especially considering the ART technique, is its low cost when compared with the Fuji IX varnish (the cost of the varnish is approximately 30 times higher when compared with nail varnish), and, at present, the varnish supplied by the Fuji IX material is light-activated, thus preventing its very use with the ART technique, created to be used without electrical power.

The present study also demonstrated that for some of the GICs, at the different storage times studied, there was no statistically significant difference between the mean microhardness values in the presence of surface protection (nail varnish or varnish) or in its absence. However, it is suggested that surface protection should be performed, due to the prolonged setting reaction of the material and its great susceptibility to absorbing or losing water.

In view of the results obtained in this research, one can infer that the GIC Fuji IX, indicated for the ART technique, presented the best mean microhardness values when compared with the other materials tested, but its high cost makes it difficult to use in public health. Among the Brazilian materials tested, the GIC Maxxion R presented the best performance and can be indicated for this purpose.

\section{Conclusions}

This research showed that the GICs indicated for the ART technique present higher mean surface microhardness values than the conventional GIC tested, and that different surface protection treatments and storage times could alter these microhardness values.

\section{Acknowledgements}

We wish to thank Professor Ivan Balducci for the statistical analysis. 


\section{References}

1. Frencken JE, Songpaisan Y, Phantumvanit P, Pilot T. An atraumatic restorative treatment (ART) technique: evaluation after one year. Int Dent J. 1994 Oct;44(5):460-4.

2. Caldas Júnior AF, Marcenes W, Sheiham A. Reasons for tooth extraction in a Brazilian population. Int Dent J. 2000 Oct;50(5):267-73.

3. Yap AUJ, Cheang PHN, Chay PL. Mechanical properties of two restorative reinforced glass-ionomer cements. J Oral Rehabil. 2002 Jul;29(7):682-8.

4. Guggenberger R, May R, Stefan KP. New trends in glassionomer chemistry. Biomaterials. 1998 Mar;19(6):479-83.

5. Peutzfeldt A, García-Godoy F, Asmussen E. Surface hardness and wear of glass ionomers and compomers. Am J Dent. 1997 Feb;10(1):15-7.

6. Mount GJ. Atlas de cimento de ionômero de vidro: guia para o clínico. $2^{\text {a }}$ ed. São Paulo: Santos; 1996.

7. Ellakuria J, Triana R, Mínguez N, Soler I, Ibaseta G, Maza $\mathrm{J}$ et al. Effect of one-year water storage on the surface microhardness of resin-modified versus conventional glass ionomer cements. Dent Mater. 2003 Jun;19(4):286-90.

8. Hotta M, Hirukawa H, Yamamoto K. Effect of coating materials on restorative glass-ionomer cement surface. Oper Dent. 1992 Mar/Apr;17(2):57-61.

9. Serra MC, Navarro MFL, Freitas SFT, Carvalho RM, Cury JA, Retief H. Glass ionomer cement surface protection. Am J Dent. 1994 Aug;7(4):203-6.

10. Valera VC, Navarro MFL, Taga EM, Pascotto RC. Effect of nail varnishes and petroleum jelly combinations on glass ionomer dye uptake. Am J Dent. 1997 Oct;10(5):251-3.

11. Watson T, Banerjee A. Effectiveness of glass ionomer surface protection treatments: a scanning optical microscope study. Eur J Prosthodont Rest Dent. 1993 Dec;2(2):85-90.

12. Raggio DP. Dureza Knoop de cimentos de ionômero de vidro indicados para o tratamento restaurador atraumático (TRA) [thesis]. São Paulo: Faculdade de Odontologia da USP, Universidade de São Paulo; 2004.
13. Cerqueira-Leite JBB, Giro EMA, Cruz CAS. Estudo comparativo da dureza superficial de cimentos ionoméricos restauradores submetidos a condições de umidade e dessecamento. Rev Odontol UNESP. 1999 jan/jun;28(1):119-35.

14. Anusavice KJ (editor). Phillips, materiais dentários. $11^{\text {a }}$ ed. Rio de Janeiro: Elsevier; 2005.

15. Aliping-McKenzie M, Linden RWA, Nicholson JW. The effect of saliva on surface hardness and water sorption of glass ionomers and compomers. J Mater Sci Mater Med. 2003 Oct;14(10):869-73.

16. Hotta M, Hirukawa H, Aono M. The effect of glaze on restorative glass-ionomer cements: evaluation of environmental durability in lactic acid solution. J Oral Rehabil. 1995 Sep;22(9):685-9.

17. Okada K, Tosaki S, Hirota K, Hume WR. Surface hardness change of restorative filling materials stored in saliva. Dent Mater. 2001 Jan;17(1):34-9.

18. Wang XY, Yap AUJ, Ngo HC, Chung SM. Environmental degradation of glass-ionomer cements: a depth-sensing microindentation study. J Biomed Mater Res B Appl Biomater. 2007 Jul;82(1):1-6 [cited 2007 Mar 01]. Abstract available from: http://www3.interscience.wiley.com/journal/113391973/ abstract.

19. Xie D, Brantley WA, Culbertson BM, Wang G. Mechanical properties and microstructures of glass-ionomer cements. Dent Mater. 2000 Mar;16(2):129-38.

20. Yap AUJ, Wang X, Wu X, Chung SM. Comparative hardness and modulus of tooth-colored restoratives: a depth-sensing microindentation study. Biomaterials. 2004 May;25(11):217985.

21. Yao K, Chien M, Kohara, Chikamori M, Kushida K, Hieda T. Effect of water isolation and early finishing on hardness of glass ionomer cements. J Osaka Dent Univ. 1990 Oct;24(2):141-7.

22. Earl MSA, Mount GJ, Hume WR. The effect of varnishes and other surface treatments on water movement across glass ionomer cement surface II. Austr Dent J. 1989 Aug;34(4):326-9. 